\title{
SEKOPER CINTA: SEKOLAH PENINGKATAN KUALITAS PEREMPUAN DI TATAR SUNDA
}

\author{
Neng Eri Sofiana \\ Pesantren Mahasiswa Al-Mutawakkil Ponorogo.nengerisofiana@yaboo.com
}

\author{
๑๑ \\ (C)2020 by the authors. Submitted for possible open access publication under the terms and conditions \\ of the Creative Commons Attribution-ShareAlike 4.0 International License (CC-BY-SA) \\ license (https://creativecommons.org/licenses/by-sa/4.0/) \\ d) DOI : http://dx.doi.org/10.30983/humanisme.v4i2
}

\begin{abstract}
West Java for the past three years has been included in the top three provinces with the highest number of divorces and the highest rate of child violence. Ridwan Kamil and the Chief of the West Java PKK launched 'Sekoper Cinta' or women's school beld by the DP3AKB which make an affort to empower women to achieve equality, participation, access, roles, benefits and control between women and men in all fields. This school has beld a graduation ceremony for 2,700 women on October 22, 2019. This program is beld to improve the quality of women so they can reduce the rate of divorce and violence against children. So, how is this program carried out in West Java, can it reduce the existing divorce rate? Can it be applied in other areas as a solution to protect women and children? In fact, Sekoper Cinta is able to make women and mothers more empowered and qualified with a lot of materials that encourage family resilience and economic independence, so that if applied it will certainly be able to reduce the divorce rate in West Java and this program can be used as guidelines and examples for other areas because the results are able to give freedom to women from gender injustice.
\end{abstract}

Keywords: Sekoper Cinta, Woman's quality, Tatar Sunda.

\begin{abstract}
Abstrak
Jawa Barat selama tiga tahun terakhir ini termasuk ke dalam tiga besar provinsi dengan jumlah perceraian terbanyak dan angka kekerasan anak terbesar. Ridwan Kamil beserta Ketua PKK Jawa Barat meluncurkan 'Sekoper Cinta' atau Sekolah Perempuan Capai Impian dan Cita-Cita sebagai sekolah khusus perempuan yang diadakan oleh Pemprov Jawa Barat dengan Dinas Pemberdayaan Perempuan Perlindungan Anak dan Keluarga Berencana (DP3AKB) yang berupaya dalam memberdayakan para perempuan demi mewujudkan kesetaraan, partisipasi, akses, peran, manfaat, dan kontrol antara perempuan dan laki-laki di semua bidang. Sekolah ini telah mengadakan wisuda bagi 2.700 perempuan pada 22 Oktober 2019 lalu. Program ini diadakan sebagai salah satu upaya untuk meningkatkan kualitas perempuan sehingga dapat menekan angka perceraian dan kekerasan terhadap anak. Maka, bagaimana program ini dilakukan di Jawa Barat, apakah dapat menekan angka perceraian yang ada? Apakah mampu diterapkan di wilayah lain sebagai solusi melindungi kaum perempuan dan anak? Ternyata, Sekoper Cinta mampu membuat perempuan dan ibu-ibu lebih berdaya dan berkualitas dengan sekian banyak materi yang mendorong kepada ketahanan keluarga dan kemandirian ekonomi, sehingga jika diaplikasikan tentu akan mampu menekan angka perceraian yang ada di Jawa Barat dan program ini dapat dijadikan pedoman serta contoh bagi wilayah lainnya karena hasilnya yang mampu memberi kebebasan kepada perempuan dari ketidakadilan gender.
\end{abstract}

Kata Kunci: Sekoper Cinta, Kualitas perempuan, Tatar Sunda. 


\section{Latar Belakang}

Di Tatar Sunda masih menjadi hal yang tabu bagi perempuan untuk mendapatkan pendidikan yang tinggi. Sehingga sedikit yang dapat meneruskan pendidikan sampai sekolah menengah atas, apalagi hingga tingkat perguruan tinggi karena kebanyakan berhenti di SD atau SMP saja. Pendidikan rendah yang dimiliki perempuan Sunda ini mengantarkan pada pernikahan dini, hal ini karena masyarakat Sunda masih banyak yang beranggapan bahwa setinggi apapun pendidikan perempuan tetap akan kembali ke dapur, maka terdapat pola pikiran untuk menikahkan anaknya di usia muda sehingga terbebas beban biaya sekolah dibandingkan dengan menyekolahkan anak perempuan yang akan mengeluarkan biaya sekolah lebih tinggi.

Pernikahan dini yang dilakukan terkadang di bawah usia pernikahan yang ditetapkan peraturan, bahkan membuat usia lebih tua agar dapat mencapai usia pernikahan yang diatur dalam undangundang. Hal ini membuat pernikahan yang dijalani hanya berumur jagung, banyak yang kandas di perceraian. Sehingga Jawa Barat menjadi salah satu provinsi dengan angka perceraian tertinggi. Pada tahun $2015,{ }^{1}$ angka talak dan cerai di Jawa Barat berada pada angka 70.293 kasus yang berarti menduduki peringkat ketiga setelah Jawa Timur $(87.475$ kasus) dan Jawa Tengah (71.901 kasus), kemudian pada tahun 2016 menjadi 75.001 kasus atau peringkat kedua setelah Jawa Timur (86.491 kasus), dan pada tahun 2017 kembali naik menjadi 79.047 setelah Jawa Timur (84.839 kasus) padahal jika dibandingkan dengan angka perceraian di

1 Thareq Akmal, Tiga Provinsi dengan Jumlab Perceraian Tertinggi (Desember 2018) dalam https://smartlegal.id/smarticle/layanan/2018/12/20/ tiga-provinsi-dengan-jumlah-perceraian-tertinggi.

Diakses pada Kamis 21 November 2019, jam 12:58.
Jawa Timur dan Jawa Tengah yang setiap tahun menurun, Jawa Barat menunjukkan kenaikan di angka tersebut.

Tidak hanya berdampak pada perceraian, pernikahan di Jawa Barat sangat rentan dengan kasus kekerasan. Pada tahun 2018, Provinsi Jawa Barat mempunyai 613 korban perempuan dari 819 kasus kekerasan yang tercatat di KPPA. ${ }^{2}$ Selain itu terdapat kasus perdagangan manusia sebanyak 278 kasus selama tahun 2009 hingga 2015. ${ }^{3}$ Tidak hanya itu, Jawa Barat menyumbang 29,9 persen atau sekitar 2,7 juta balita dari 36 persen balita (0-5 tahun) yang terkena stunting di Indonesia. ${ }^{4} \mathrm{Hal}$ ini tentu bukanlah suatu hal yang dapat dibanggakan. Selain dampak di atas, pernikahan dini memberikan dampak buruk bagi perempuan, karena dipaksa melakukan praktik biologis lebih dini seperti hamil, melahirkan, nifas, dan menyusui.

Nur Rofiah dan Kustini mengatakan dalam kasus perkawinan di bawah umur, perspektif perempuan sangat diperlukan, karena risiko yang dialami perempuan jauh lebih besar, seperti belum menyadari peralihan status sebagai seorang istri sehingga

2 Windiyati Retno, Ada 819 Kekerasan pada Anak di Jabar selama 2018 Terbanyak Sukabumi (2019), dalam https://www.pikiran-rakyat.com/jawabarat/2019/04/03/ada-819-kasus-kekerasan-padaanak-di-jabar-2018-terbanyak-di-sukabumi. Diakses pada Kamis 21 November 2019, jam 12:49.

${ }^{3}$ Kasim, Kasus Kekerasan Anak dan Perempuan Ada di Jawa Barat (2015) dalam https:// fokusjabar.com/m/berita-pantura/kasuskekerasan-anak-dan-perempuan-tertinggi-ada-di-jawabarat-h32714.html. Diakses pada Kamis 21 November 2019, jam 12:50.

4 Debbie Sutrisno, Turunkan Angka Stunting, Pemprov Jabar Luncurkan Desa Cageur (November 2019) dalam

https://jabar.idntimes.com/newa/jabar/debbiesutrisno/turunkan-angka-stunting-pemprov-jabarluncurkan-desa-cageur/full. Diakses pada Kamis 21 November 2019, jam 13:08. 
masih bersikap kekanak-kanakan, tidak mengetahui haknya dengan baik sehingga hanya bisa menuruti apa yang diperintahkan kepadanya, kesulitan beradaptasi, dan hal lainnya. ${ }^{5}$ Maka, perlu adanya langkah khusus untuk menanggulangi sekian banyak permasalahan di atas.

Dalam penelitian yang dilakukan Ramdani Wahyu Sururie dan Harry Yuniardi ditemukan bahwa penyebab perceraian tinggi di Jawa Barat adalah faktor ekonomi, komitmen yang kurang, ketidakpahaman akan esensi perkawinan, lalu tidak adanya keharmonisan dan tanggungjawab. Perceraian banyak terjadi dibandingkan dengan perkawinan. Hal ini sesuai dengan data dari stadok Badilag tahun 2012-2016 yang menunjukkan bahwa persentase perceraian dengan nikah pada tahun 2012-2016 secara berturut-turut ialah 12\%,12\%,15\%,16\% dan $19 \%$ dengan didominasi oleh pasangan berusia 30-40 tahun, kemudian usia 21-30 tahun dan pasangan yang berpendidikan SD dan SMP. Adapun strategi yang disarankan ialah pertama, memberikan pendidikan dalam keluarga, khususnya pendidikan agama. Kedua, pendidikan pra nikah mulai dari fiqh munakahat, manajemen keuangan keluarga, psikologi keluarga, dan teknik menyelesaikan konflik. Ketiga, pembenahan pemeriksaan perceraian di Pengadilan Agama seperti dengan pemberian hadiah untuk hakim yang berhasil menjadi mediator, keberanian hakim menolak permohonan cerai, pembenahan dalam putusan verstek, dan menyelenggarakan program ketahanan keluarga. ${ }^{6}$

Untuk menanggulangi tingginya angka perceraian di Jawa Barat memang membutuhkan kerjasama semua pihak, baik

5 Nur Rofiah dan Kustini, "Perkawinan di Bawah Umur (Potret Buram Anak Perempuan di Cainjur", Jurnal Harmoni, 2014, 148.

${ }^{6}$ Ramdani Wahyu Sururie dan Harry Yuniardi, "Perceraian Dalam Keluarga Muslim di Jawa Barat", Jurnal Al-Manahij, Vol. 12, 2018, 272. itu pasangan, keluarga, masyarakat, dan pemerintah. Sekoper Cinta adalah salah satu cara yang dilakukan pemerintahan provinsi Jawa Barat dalam menanggulangi angka perceraian tinggi di Tatar Sunda ini. Ia merupakan sekolah khusus perempuan yang dicanangkan untuk dapat memberdayakan para perempuan demi mewujudkan kesetaraan partisipasi, akses, peran, manfaat, dan kontrol antara perempuan dan laki-laki di semua bidang. Sekolah ini telah mengadakan wisuda bagi 2.700 perempuan pada 22 Oktober 2019 lalu.

Adapun penelitian terdahulu "Proses Pemberdayaan pada Program Sekolah Perempuan Capai Impian da Cita-cita (Sekoper Cinta)" yang dilakukan oleh Dini Anjani Nurlatifah, Deden Sumpena, dan Anjani Hilman menilai Sekoper Cinta merupakan program pemberdayaan yang cukup efektif, sistematis, dan aplikatif. ${ }^{7}$ Kemudian terdapat skripsi yang ditulis oleh Tirza Fitri Febriyanti dengan judul "Pemberdayaan Perempuan dalam Meningkatkan Pendidikan Karakter Melalui Program Sekoper Cinta (Sekolah Perempuan Capai Impian dan Cita-Cita) di Kota Bandung: Studi Deskriptif DP3APM Kota Bandung" menyatakan bahwa program Sekoper Cinta adalah salah satu program unggulan provinsi Jawa Barat untuk mewujudkan perempuan juara yang fokus pada pemberdayaan perempuan melalui keterampilan, pengetahuan dan kekuasaan mengenai karakter. $^{8}$

Dari penelitian ini tidak membahas bagaimana program dapat dikatakan sebagai

7 Dini Anjani Nurlatifah, dkk, "Proses Pemberdayaan pada Program Sekolah Perempuan Capai Impian da Cita-cita (Sekoper Cinta)", Az-Zahra, Vol.1 No. 1, 2020.

8 Tirza Fitri Febriyanti, Pemberdayaan Perempuan dalam Menngkatkan Pendidikan Karakter Melalui Program Sekoper Cinta (Sekolah Perempuan Capai Impian dan CitaCita) di Kota Bandung: Studi Deskriptif DP3APM Kota Bandung (Skrispi Universitas Pendidikan Indonesia, 2019). 
program pemberdayaan perempuan dan sejauh mana dapat memberdayakan para peserta peserta program tersebut. Adapun penelitian selanjutnya ini ialah penelitian kualitatif dengan metode analisis deskriptif dalam upaya mencari data, mengolah, dan mengalinisisnya. Data diperoleh dari laporan kegiatan yang diunggah oleh berbagai pihak, seperti Ridwan Kamil sebagai Gubernur Jawa Barat dan admin Sekoper Cinta yang kemudian diolah dengan intensif dan dilengkapi dengan wawancara kepada berbagai pihak yang terkait, seperti pegawai desa Sindanglaya dan masyarakat umum untuk melihat eksistensi Sekoper Cinta di wilayah Jawa Barat. Penelitian ini akan melihat pelaksanaan dan pengaruh Sekoper Cinta dalam menekan angka perceraian dan kekerasan di Jawa Barat, serta kemungkinan penerapannya di wilayah lain sebagai solusi peningkatan kualitas perempuan sekaligus melindungi kaum perempuan dan anak.

\section{Peran Perempuan dalam Keluarga}

Keluarga sebagai institusi sosial terkecil yang menjadi fondasi dari investasi awal untuk membangun bangsa inilah pertama kalinya kehidupan seseorang dimulai. Begitu pula dalam hal pendidikan, pendidikan pertama didapatkan dari keluarga, karena keluarga adalah tempat untuk mendidik anak memiliki pengetahuan, pengalaman, kepandaian, dan perilaku yang baik. Keluarga memiliki peran yang sangat besar bagi kesejahteraan dan kelestarian anggotanya, termasuk perkembangan dan pembentukan pribadi anak.

Dalam teori Tabula rasa, setiap manusia yang dilahirkan dengan jiwa yang kosong layaknya selembar kertas putih yang

9 M. Syahran Jailani, “Teori Pendidikan Keluarga dan Tanggung Jawab Orang Tua dalam Pendidikan Anak Usia Dini”, Nadwa: Jurnal Pendidikan Islam, Vol. 8 No. 2, 2014, 246. belum diberi tulisan apapun. Kertas itu akan mulai terisi melalui pengalaman-pengalaman sedari kecil melalui alat inderanya. Dalam hal ini John Locke menambahkan bahwa pendidik pertama seorang individu ialah keluarga, dan keluargalah yang pertama mengisi kertas kosong tersebut.

Senada dengan William J.Goode, keberhasilan siswa dalam pendidikan tidak hanya karena mutu instansi pendidikan tersebut, tetapi juga merupakan keberhasilan keluarga dalam menyiapkan dan mendidik anak-anaknya. Kemudian dikuatkan oleh Hurlock bahwa pola asuh dalam keluarga, menentukan kualitas perkembangan dan kepribadian anak. Kemudian Ki Hajar Dewantara juga menegaskan bahwa keluarga adalah salah satu tri pusat pendidikan yang mendidik anak mulai dari menyusui, mengajarkan bahasa ibu, dan mendidik anak untuk masuk gerbang pernikahan. ${ }^{10}$

Di dalam keluarga terdapat pembagian tugas dan kerja, serta hak dan kewajiban memenuhi kebutuhan keluarga meliputi kebutuhan spiritual, psikologis, sandang, pangan, dan papan. ${ }^{11}$ Berdasarkan pendekatan sosio kultural, beberapa fungsi keluarga ialah fungsi biologis, fungsi religius, fungsi perlindungan, fungsi kasih sayang, fungsi ekonomis, fungsi refrektif, kemudian fungsi pendidikan sebagai institusi pendidikan kemudian fungsi sosialisasi sebagai tempat mempersiapkan anak menjadi anggota masyarakat yang baik. ${ }^{12}$ Secara umum, peran

${ }^{10}$ Made Pidarta, Peranan Ibu Dalam Pendidikan Anak, Jurnal Imu Pendidikan, Vol. 4 Nomor 4, 1997, 241.

11 Jasmienti dan Nofrianti Putri Utami, Peran Perempuan Single Mother dalam Keluarga Miskin di Jorong Balai Mansiro Nagari Guguak VIII Koto, Humanisma: Journal of Gender Studies, Vol. 3, No. 02, 2019, 130.

12 Istina Rakhmawati, "Peran Keluarga dalam Pengasuhan Anak", Jurnal Bimbingan Koseling Islam, Vol. 6, 2015, 7 . 
ayah dan ibu sama dalam keluarga, namun terdapat sentuhan yang berbeda.

Peran seorang ibu yang lembut dan penuh kasih sayang lebih dominan kepada mengelola perasaan sayang dan cinta, serta memupuk kemampuan berbahasa, sedangkan peran ayah ialah menumbuhkan kompetensi anak, mengajarkan anak akan tanggung jawab dan semangat berprestasi. Adapun peran dalam perkawinan menurut Parsons dan Bales's terbagi menjadi instrumental dan ekspresif. Peran instrumental ialah peran mencari uang dan memberi kepuasan dengan sistem ekonomi dan sekolah, sedangkan peran ekspresif ialah peran memerhatikan hubungan dengan memberi kepuasaan dan ekspresi perasaan yang berhubungan dengan hubungan intim. ${ }^{13}$

Sejatinya terdapat empat model peran dalam keluarga, yakni komplementaris atau saling melengkapi dengan peran yang berbeda, pertukaran peran karena terjadi respon dari permintaan untuk bertukar peran, konflik peran ketika terjadi perselisihan tentang suatu peran, dan kebalikan peran ketika anggota keluarganya melakukan peran yang berlawanan ketika biasanya. Namun secara dominan, peran instrumental banyak dilakukan oleh ayah, sedangkan fungsi ekpresif diperankan oleh ibu.

Alimatul Qibtiyah menjelaskan ciri-ciri keluarga ideal sebagai keluarga dengan relasi yang seimbang, tidak terdapat kekerasan, terjaminnya pertumbuhan dan perkembangan yang baik, terpenuhinya kebutuhan dasarnya, adanya keyakinan akan mulianya semua peran dan penuh kemaslahatan. ${ }^{14}$ Selanjutnya pendidikan keluarga merupakan tanggung jawab kedua orangtua dalam memberikan penanaman nilai dan teladan. Sehingga ayah

13 Ummu Hani Almasitoh, "Model Terapi dalam Keluarga,” Jurnal Magistra, No. 08, 2016, 27.

14 Alimatul Qibtiyah, Feminisme Muslim di Indonesia (Yogyakarta: Penerbit Suara Muhammadiyah, 2018), 206. dan ibu berperan sebagai pengajar, pendidik, pembimbing dan penuntun bagi anak. Parenting atau pengasuhan dalam arti mendidik ini dilakukan dari anak lahir hingga memasuki masa dewasa, karena pola perilaku anak dipengaruhi oleh pola pengasuhan dan pendidikan sejak dini. Oleh karena itu, pendidikan di dalam keluarga merupakan hal yang penting sebagai dasar, kemudian didukung oleh sekolah dan lingkungan anak.

Kedua orangtua wajib bekerjasama dalam membangun keluarga dan memikul tanggung jawab serta saling melengkapi dalam melaksanakan tugas. Terlebih ibu yang dikatakan sebagai sekolah pertama bagi anaknya. ${ }^{15}$ Tugas ini jika dilakukan dengan sempurna, maka menurut Abdullah Nashih Ulawan dapat menghasilkan hasil yang baik, yakni terbentuknya anak-anak yang shalih dan terdidiknya generasi yang beriman. Peranan seorang perempuan telah tercatat sepanjang sejarah sebagai seorang yang mengandung, melahirkan, merawat, membesarkan dan mendidik anak-anaknya.

Pendidikan yang diberikan seorang ibu tidak terbatas hanya setelah anak dilahirkan, melainkan sudah dilakukan sejak dalam kandungan. Selain itu, peran perempuan dalam keluarga juga merupakan bagian dari peranannya di dalam masyarakat. ${ }^{16}$ Menurut Vivikenanda, negara dan bangsa akan sejahtera dan maju jika menghormati perempuan dan tidak membiarkan perempuan tertinggal, tertindas, dan tersisihkan. ${ }^{17}$ Pengaruh pendidikan yang besar

15 Abdullah Nashih Ulwan, Pendidikan Anak dalam Islam (Tarbiyatul Aulad fil Islam), Penterj. Arif Rahman Hakim dan Abdullah Halim (Solo: Insan Kamil, 2012), 7.

16 Indah aswiyati, Peran Wanita dalam Menunjang Perekonomian Rumah Tangga Keluarga Petani Tradisional Untuk Penanggulangan Kemiskinan Di Desa Kuwil Kecamatan Kalawat, Jurnal Holistik, No. 17, 2016, 5.

17 Siti Zahrok dan Wayan Suarmini, "Peran Perempuan dalam Keluarga", Prosiding Semateksos 3 
dalam keluarga ada pada seorang ibu, karena ia memiliki sifat keibuan yang luar biasa, ${ }^{18}$ kemudian dilengkapi dengan keterlibatan seorang ayah. Dalam pendidikannya, seorang ibu dapat menjadi pemuas kebutuhan, teladan, dan pemberi stimulus bagi perkembangan anak.

Ija Suntana menegaskan seorang ibu sebagai sosok pengasih yang harus dipuja, tahu segala hal, selalu ada dan mampu membantu anak. ${ }^{19}$ Sehingga seorang ibu dituntut untuk bisa menguasai dan memahami tentang kesehatan, kebersihan, ahli gizi, keuangan, manajemen waktu, guru dan psikologi. Hal ini menunjukkan bahwa tidaklah mudah menjadi seorang ibu, maka pendidikan dan pengetahuan serta persiapan menjadi seorang ibu hasruslah menjadi hal yang dimiliki setiap perempuan. Selain itu, perempuan yang mendapatkan pendidikan layak, tentu akan dapat memotong patriarki di dalam rumah, termasuk dalam tindakan yang membedakan anak laki-laki dan anak perempuan yang mengarahkan anak perempuan untuk selalu membantu ibu di dapur, padahal anak laki-laki dan anak perempuan mempunyai tanggung jawab yang sama di dalam keluarga. Persoalan ini juga akan berakibat pada kesempatan keterlibatan yang sama di masyarakat. Maka, perempuan menjadi subjek penting dalam pendidikan di keluarga. ${ }^{20}$

Startegi Pembangunan Nasional Menghadapi Revolusi Industri 4.0, 61 .

18 Agustin Hanapi, Peran Perempuan Dalam Islam, Gender Equality: Internasional Journal of Child And Gender Studies, Vol. 1, No. 1, 2015, 16.

${ }^{19}$ Safaruddin dan Jumanto, "Peran Ibu dalam Pendidikan Keluarga Untuk Mendukung Keberhasilan Pendidikan Formal Anak di Sekolah Dasar", Jurnal Profesi Pendidik, Vol. 3, 2016, 45.

${ }^{20}$ Dian Lestari, Eksistensi Perempuan dalam Keluarga (Kajian Peran Perempuan sebagai Jantung Pendidikan anak), Muwazah, Vol. 8, No. 2, 2016, 259.
Selain dari hal yang disebutkan di atas, kualitas anggota keluarga juga tentu mempengaruhi kualitas dan ketahanan keluarga. Penguatan kualitas anggota keluarga sama dengan penguatan kualitas dan ketahanan keluarga itu sendiri.

\section{Sekolah Perempuan Capai Impian dan Cita - cita (Sekoper Cinta) sebagai Program Peningkatan Kualitas Perempuan dan Upaya Penanggulan Perceraian di Tatar Sunda}

Keluarga yang sakinah, mawaddab warahmah serta maslahah merupakan dambaan setiap keluarga, karena dengan suasana demikian akan merasakan suasana surga bagi seluruh penghuninya. Untuk mencapai keluarga yang demikian, tentu diperlukan pemahaman akan adanya kesalingan atau kerjasama dalam mencapai dambaan tersebut, termasuk dalam berbagi peran secara fleksibel tanpa melihat jenis kelamin, tapi melihat pada kemampuan dan kemungkinan untuk melakukan suatu hal. Sehingga tidak terkekang pada pemahaman perempuan yang lemah dan laki-laki yang kuat, maka kemudian menghasilkan pemahamanan bahwa perempuan harus dilindungi oleh lakilaki. Selain anggapan ini, lahir anggapan lain seperti peran tradisi perempuan sebagai orang yang bertugas di area domestik, dan laki-laki yang bertugas di area publik, kemudian dwi peran di mana perempuan yang bekerja di ruang publik tetap dibebani urusan domestik, dan anggapan lainnya. ${ }^{21}$

Keluarga sakinah perspektif kesetaraan menegaskan bahwa laki-laki dan perempuan memiliki kedudukan yang sama sebagai

21 Zuwardi, Peran Perempuan dalam Mewujudkan Keluarga Sejahtera Menurut Perspektif Ekonomi Islam (Studi Kasus Perempuan Pedagang Kaki Lia di Simpang Tugu Togo Baleh, Kelurahan Pakan Labuha, Kota Bukittinggi, Humanisma:Journal of Gender Studies, Vol 04 No. 01, 2020, 65. 
hamba Allah dan khalifah di muka bumi, kemudian diciptakan dari bahan dan melalui proses yang sama, nilainya ditentukan oleh ketaqwaan, keduanya sama-sama menjadi pelindung satu sama lain dan akan kembali pada Allah sebagai dirinya sendiri ${ }^{22}$ kemudian juga sama-sama terlibat dalam perjanjian primordial. $^{23}$

Pemahaman ini menjadi sangat penting, karena konstruksi patriaki yang terkadang akan berdampak pada penindasan atau subordinasi terhadap perempuan. ${ }^{24}$ Dalam mencapai pemahaman ini, diperlukan upaya untuk memberdayakan perempuan dengan memberikan akses pendidikan yang baik, sehingga perempuan dapat memahami hakikat dirinya sendiri dengan baik pula. Mengingat pendidikan merupakan cara untuk membentuk sumber daya manusia yang produktif dan inovatif, selain itu juga untuk mentransformasikan nilai-nilai kognitif, afektif, psikomotorik, dan nilai-nilai yang berguna dalam kehidupan. ${ }^{25}$ Terlebih John Locke mengatakan bahwa manusia terlahir seperti selembar kertas putih, maka ada proses membuat kertas tersebut berisikan tulisan dan warna. Tugas ini berada dalam sebuah keluarga.

Keluarga tempat dimana ada ayah, ibu dan anak yang hidup bersama dengan kasih sayang, tentu ingin memberikan tulisan dan warna terbaik dalam kertas putih yang

${ }^{22}$ Nur Rofiah, "Kekerasan Dalam Rumah Tangga Dalam Perspektif Islam”, Jurnal Wawasan: Jurnal Ilmiah Agama dan Sosial Budaya, Vol. 1, 2017, h. 41-42.

23 Hasnani Siri, Gender Dalam Perspektif Islam, Jurnal Al-Maiyyah, Volume 07 No. 2 JuliDesember 2014, 247.

24 Nurfarida Deliana, Gerakan Emansipasi Ruhana Kuddus dalam Memperjuangkan Kesetaraan Pendidikan Perempuan di Minangkabau, Humanisma:Journal of Gender Studies, Vol 03 No. 02, 2019, 171.

${ }^{25}$ Rustan Efendy, Kesetaraan Gender Dalam Pendidikan, Jurnal Al-Maiyyah, Volume 07 No. 2, 2014, 156. dimilikinya. Sebuah ketahanan keluarga akan kokoh jika seorang ibu berkualitas. Hal ini dikarenakan seorang ibu sebagai pendidik dan sekolah pertama bagi anak-anaknya. Seorang perempuan mempunyai peran aktif dalam ketahanan keluarga dan kualitas anak. Semakin berpendidikan seorang perempuan, maka bisa menjadi salah satu faktor pendukung dalam mempertahankan ketahanan keluarga, berperan dalam kemajuan dan perkembangan putra-putrinya. Perempuan akan menjadi pusat peradaban yang darinya masa depan bangsa dipertaruhkan. ${ }^{26}$ Terlebih terdapat hadits yag menyatakan bahwa "wanita adalah tiang negara, jika wanitanya baik maka baiklah negara, dan bila wanita buruk maka negara juga ikut buruk.". ${ }^{27}$

Namun sayangnya, seorang perempuan di Jawa Barat dianggap tidak perlu mendapat pendidikan tinggi, cukup bisa membaca, menulis, dan menghitung. Sehingga masih banyak perempuan yang hanya bersekolah hingga SMP bahkan SD. Kemudian banyak yang menikahkan anaknya di usia belia yang berakibat kepada timbulnya perceraian dan kekerasan rumah tangga. Padahal baik perempuan maupun laki-laki mempunyai kesempatan yang sama untuk mendapat pendidikan. Apalagi pendidikan tentang keluarga bagi perempuan yang akan menjadi sekolah pertama bagi generasi yang dilahirkannya.

Hal ini tentu saja membuat perempuan seharusnya mendapat pendidikan khusus, baik ilmu atau pengetahuan umum baik bagi perempuan kelas bawah, menengah, maupun kelas atas, ${ }^{28}$ karena nantinya untuk mencapai

${ }^{26}$ Husein Muhammad, Islam dan Pendidikan Perempuan, Jurnal Pendidikan Islam, Vol. III, No. 2, 2014, 238.

27 Deni Febrini, Bunga Rampai Islam dan Gender (Yogyakarta: Pustaka Pelajar, 2017), 133.

28 Lihat pendapat lain di Siti Ruhaini Dzuhayatin, Rezim Gender Muhammadiyah (Yogyakarta: Suka Press UIN Sunan Kalijaga Yogyakarta dan Pustaka Pelajar, 2015), 288. 
generasi yang unggul. Kemudian konsep pendidikan perempuan bukan hanya tentang memberi kesempatan masuk kelas kepada perempuan, namun juga memberikan kurikulum sesuai kebutuhan perempuan ke depan. $^{29}$

Sosok-sosok perempuan Sunda dahulu sudah memiliki semangat dan daya juang dalam pendidikan perempuan, seperti Raden Dewi Sartika yang lahir pada tahun 1884 ini telah mendirikan Sakola Istri atau Sekolah Perempuan pada tahun 1904 yang masih berdiri kokoh hingga sekarang. ${ }^{30}$ Sekolah perempuan ini dulunya didirikan di Paseban Kulon Pendopo Kabupaten Bandung yang kini berada di Jalan Keutamaan Istri No. 12 Balong Gede - Regol - Bandung. Kini berubah nama menjadi Sekolah Dewi Sartika. Ini menjadi sekolah pertama bagi gadis-gadis Indonesia dengan menerapkan kurikulum Sekolah Kelas Dua atau Tweede Klasse Inlandshe School dengan dilengkapi materi keterampilan seperti cara membuat batik, cara jahit, menisik, cara membuat renda, dan cara membuat sulaman juga kegitan area domestik seperti cara membuat masakan, mencuci, menyetrika, dan lain sebagainya. Kemudian Raden Ayu Lasminingrat sebagai tokoh emansipasi wanita, pelopor pendidikan dan aktivis perempuan Sunda yang telah memiliki banyak jasa dalam kepenulisan sehingga dihormati sebagai peletak dasar sastra Sunda modern. ${ }^{31}$

Raden Ayu Lasminingrat yang lahir pada tahun 1843 ini dapat dikatakan sebagai tokoh intelektual perempuan pertama di

29 Erma Pawitasari, Pendidikan Khusus Perempuan antara Kesetaraan Gender dan Islam, Tsaqafah, Vol. II, No. 2, 2015, 264.

30 Lihat Sekolah Dewi Sartika di www.disparbud.jabarprov.go.id/wisata/).

${ }^{31}$ Lihat Raden Ayu Lasminingrat: Intelektual

Pertama di Indonesia di

https://www.jelajahgarut.com/raden-ayulasminingrat).
Indonesia karena telah lahir sebelum R.A Kartini, Dewi Sartika dan Cut Nyak Dien. Sebelum ketiganya lahir, Raden Ayu Lasminingrat telah menerjemahkan dan menerbitkan buku-buku yang dijadikan buku bacaan wajib di HIS, Schakelschool dan sekolah lainnya hingga akhir masa penjajahan Belanda. Ia telah banyak menulis buku berbahasa Sunda yang ditujukan untuk anakanak sekolah seperti Carita Erma terjemahan dari buku Christoph von Schmid dalam aksara Jawa yang telah dicetak 1.500-3.000 eksemplar pada masa itu. Ia juga mendirikan Sekolah Keutamaan Istri pada tahun 1907 di Pendopo Kabupaten Garut yang pada masa Jepang berubah menjadi SR (Sekolah Rakyat) yang menerima murid laki-laki dan kini menjadi SDN Ranggalawe I dan IV. Sekolah ini mengajarkan baca tulis dan pemberdayaan perempuan atau hampir sama seperti Sekolah Dewi Sartika. Tujuan didirikannya sekolah ini ialah agar setelah menikah dapat membahagiakan suami dan anak, serta dapat mengerjakan sendiri segala hal dalam urusan rumah tangga.

Selain itu juga terdapat Raden Siti Jenab yang lahir pada tahun 1890 ini merupakan murid Dewi Sartika yang berperan penting dalam memberikan kesempatan mendapat pendidikan bagi para perempuan di Kabupaten Cianjur. ${ }^{32}$ Cara yang ditempuh dalam memberikan pendidikan bahasa Sunda, bahasa Melayu, bahasa Belanda, berhitung, pendidikan budi pekerti hingga pendidikan praktis bagi perempuan seperti membatik dan merenda adalah dengan berkelliling dari satu rumah ke rumah yang lain antar desa antar kampung hingga mendapat dukungan dari Juag Cicih

32 Lihat Kiprah Siti Jenab di Dunia Pendidikan, Semangat Juang Mencerdaskan Masyarakat Cianjur di https://cianjur.pojoksatu.id/baca/kiprah-siti-jenab-didunid-pendidikan-semangat-juang-mencerdaskanmasyarakat-cianjur). 
(istri Bupati Raden Muharam Wiratanukusumah) dengan membangun sekolah berbahan kayu dan bilik pada tahun 1906. Sekolah yang didirikan merupakan perpaduan antara Sakola Istri Dewi Sartika dan Sekolah Keutamaan Istri Ayu Lasminingrat, sehingga materi yang diberikan pun sama, ditambah dengan budi pekerti dan agama. Kini berubah menjadi SDN Siti Jenab 1 yang terletak di Jalan Siti Jenab Cianjur, yang pada akhir - akhir ini sedang diperebutkan oleh Pemkab Cianjur untuk dibongkar dan dijadikan kantung parkir. Ketiga Perempuan Sunda ini sudah menyadari pentingnya pendidikan bagi perempuan. Semangat itu masih ada dan dengan kompleksitas problem perempuan di era ini, sekolah perempuan tentu sangat diperlukan.

Sekoper Cinta atau Sekolah Perempuan Capai Impian dan Cita-Cita atau bisa juga disebut dengan Sekoci adalah program pemerintah provinsi Jawa Barat yang juga menjadi program quick wins 100 hari kerja Gubernur Jawa Barat. Diluncurkan oleh Ridwan Kamil sebagai Gubernur Jawa Barat pada Minggu 16 Oktober 2019 di Sabuga Bandung sebagai salah satu program yang hadir untuk merespon tingginya angka perceraian di Jawa Barat, banyaknya kasus stunting, perdagangan manusia dan kasus kekerasan terhadap perempuan dan anak. Program ini menjadi wadah perempuan Sunda Jawa Barat sebagai tempat saling tukar wawasan dan pengalaman, menemukan dan mengenali kebutuhan dan juga kepentingan perempuan yang kemudian untuk mencapai dan meningkatkan kualitas hidup perempuan serta menjadi upaya mewujudkan Perempuan Jawa Barat juara yang mampu memberdayakan diri, keluarga dan lingkungan sekitarnya. Ketua Umum Sekoper Cinta ialah istri dari Ridwan Kamil, yakni Atalia Praratya yang juga menjabat sebagai Ketua Tim
Penggerak PKK Provinsi Jawa Barat. ${ }^{33}$ Adapun pemberdayaan perempuan yang dilakukan Sekoper Cinta merupakan sebuah upaya untuk mewujudkan kesetaraan partisipasi, akses, peran, manfaat, dan kontrol antara perempuan dan laki-laki di semua bidang. ${ }^{34}$

Target Sekoper Cinta ialah perempuan dengan usia 18 tahun ke atas yang berasal dari seluruh kabupaten dan kota di Jawa Barat. Mulanya, akan dilakukan pelatihan kepada Leader Champion terpilih untuk seluruh kecamatan di masing-masing kabupaten kota, kemudian mereka akan menjadi agen utama pembentukan tingkat desa atau kelurahan di 27 kabupaten kota. Pada tanggal 6 April 2019 telah didapat 270 leader champion atau trainer dan 19 Master of Trainer (MoT) yang telah diberi pembekalan dalam ToT atau Training of Trainer di bawah leading sector Dinas Pemberdayaan Perempuan Perlindugan Anak dan Keluarga Berencana (DP3AKB). Kemudian secara keseluruhan data pada tahun 2019 dari 627 kecamatan di Jawa Barat telah terlatih lebih dari 700 leader champion. ${ }^{35}$

Sekoper Cinta telah tersebar di berbagai kabupaten dan kota di Jawa Barat seperti di Tasikmalaya, Bogor, Bekasi, Ciamis, Majalengka, Purwakarta, Sukabumi, Cianjur, Cirebon, Banjar, Karawang, Depok, Pangandaran, dan Bandung. Sekolah ini mempunyai jargon berdaya, bahagia, juara dan memiliki modul yang telah dirancang secara intensif pada ToT. Adapun materi yang diberikan merupakan materi yang jika diklasifikan terbagi menjadi materi tentang diri, rumah tangga, lingkungan,

33 Telah mendapatkan penghargaan sebagai Gender Champion Provinsi Jawa Barat Tahun 2019 kategori Pembaharaun Pemberdayaan Perempuan karena telah menjadi inisiator, pendorong, penggerak semangat literasi bagi perempuan di Jawa Barat.

34 Lihat di postingan intagram @sekoper_cinta

35 Selengkapnya

di

www.intagram/sekoper cinta. 
pengembangan usaha. ${ }^{36}$ Pertama, materi tentang diri ialah seperti penggalian potensi diri, managemen konflik dan stress. Kedua, materi tentang rumah tangga terbagi atas pemenuhan dan pengelolaan sandang pangan keluarga, pola asuh anak dan remaja, simulasi masalah keluarga, pemeliharaan rumah dan pekarangan, kesehatan reproduksi dan pengenalan penyakit, praktek makanan sehat berdasarkan konsep gizi seimbang, pengelolaan keuangan pribadi dan keluarga.

Ketiga, materi tentang lingkungan yang terdiri atas bank sampah, pengelolaan sampah dan air kotor, simulasi penanganan bencana, jamkesda, BPJS. Keempat, materi tentang pengembangan usaha seperti identifikasi potensi ekonomi di Rumah Tangga dan lingkungan sekitar, kelas batik, tata boga kreatif (kulit pisang dan kulit singkong yang diubah menjadi crispy dan cocomilk), keterampilan kreatif (pemanfaatan kain perca untuk dijadikan kalung dan dompet seperti yang dilakukan, membuat piring lidi, membuat kursi dari botol bekas), pengelolaan sumber pendanaan, manajemen pemasaran produk rumah tangga, dan pengelolaan keuangan usaha rumah tangga. Selain dari materi-materi yang telah disebutkan, fasilitator Sekoper Cinta pun melakukan kolaborasi dengan berbagai pihak, seperti kolaborasi dengan para mahasiswa Fakultas Kedokteran Gigi (FKG) Universitas Indonesia untuk menyampaikan materi seputar kesehatan gigi, kemudian berkolaborasi dengan para mahasiswa Fakultas Kesehatan Masyarakat UPN yang menyampaikan makanan sehat, melakukan senam khusus Sekoper Cinta dan botram atau makan bersama sebagai bentuk implementasi dari materi pemenuhan gizi. Selanjutnya

\footnotetext{
${ }^{36}$ Terkait modul dunggah oleh Surya "Modul Sekoper Cinta Kota Sukabumi" dalam https://id.scribd.com/document/414590694/ModulSekoper_Cinta-d-e-f diakses pada 19 September 2020.
}

Sekoper Cinta telah membuat kerjasama dengan MOGEF (Ministry of Gender Equality Family) Korea Selatan, KOICA (Korea Internastional Cooperation Agency), dan Shinhan University.

Model sekolah perempuan ini ialah sekolah non formal yang terbagi menjadi tiga tahapan. Pertama, meningkatkan pengetahuan dengan metode ceramah, membaca, menonton, tanya jawab, dan lain sebagainya. Kedua, merubah sikap dari tidak mau menjadi mau dengan metode diskusi dan berbagi, melihat contoh, bermain peran, dan refleksi. Ketiga, meningkatkan keterampilan dengan metode bermain peran, praktik dan pelatihan tata boga, tata rias, dan lain sebagainya. ${ }^{37}$

Pembelajaran Sekoper Cinta biasanya diadakan secara luar jaringan, namun ketika tahun 2020, tepatnya saat pandemi COVID19 melanda Nusantara, Sekoper Cinta menerapkan blended learning (daring dan luring) dengan didukung penayangannya setiap pukul 16.30 WIB pada setiap hari Senin, Rabu dan Jum'at mulai 12 Oktober hingga 27 November 2020 melalui stasiun televisi TVRI Jabar dan kanal Youtube Sekoper Cinta Jabar. Dengan durasi kurang lebih 30 menit, model terbaru luring ini, tidak hanya berupa teori yang dipaparkan oleh MoT, melainkan dibuat berkesinambungan dengan menggagas simulasi drama dengan karakter dan peran yang lekat dalam kehidupan rumah tangga. Setelah penayangan selama tiga kali dalam seminggu, anggota Sekoper Cinta di setiap kabupaten dan kota di Jawa Barat akan mendapatkan simulasi dari fasilitator terkait materi yang belum dipahami.

Pada episode pertama, terdapat pengenalan terkait Sekoper Cinta dari

\footnotetext{
37 Dini Anjani Nurlatifah, dkk,"Proses Pemberdayaan pada Program Sekolah Perempuan Capai Impian da Cita-cita (Sekoper Cinta)", Az-Zahra, Vol.1 No. 1, 2020, 38 .
} 
Gubernur Jawa Barat, Ketua Umum Sekoper Cinta dan Ketua Dinas Pemberdayaan Perempuan Perlindungan Anak dan Keluarga Berencana (DP3AKB), serta pengenalan tokoh simulasi drama yang diberikan nama keluarga damai. Kemudian episode ketiga membahas terkait potensi diri yang disampaikan oleh Mawar Pohan, dan materi etika dan etiket Perempuan Jawa Barat di episode empat yang disampaikan oleh Riema Afriani Kusumadewi.

Kemudian secara berurutan membahas terkait pendidikan pra-nikah (disampaikan oleh Nani Muharomah), kesehatan reproduksi dan perencanaan keluarga (disampaikan oleh Santun Bhekti Rahmah sebagai seorang dokter), komunikasi dalam keluarga (disampaikan oleh Dodddy Sholahudin sebagai seorang psikolog), pola asuh anak dan remaja (disampaikan oleh Ayuna Haziza sebagai seorang psikolog), pengelolaan keuangan pribadi dan keluarga (disampaikan oleh Bambang Rustanto), pemenuhan pangan dan sandang keluarga (disampaikan oleh Dwi Kurniasari), perawatan diri dan keluarga (disampaikan oleh Hana dari Kosmetik Wardah), pemeliharaan rumah, pekarangan, dan pengelolaan sampah rumah tangga (disampaikan oleh Tukino), pertolongan pertama pada keadaan kegawatdaruratan (yang disampaikan oleh Fina Meilyana Andriyani selaku kepala Dinas P3AKB Jawa Barat, dokter anak konsultan emergenscy dan rawat intensif anak), penyakit pada anak, penanganan dan pencegahan (yang disampaikan oleh Rodman Tarigan sebagai konsultan tumbuh kembang anak dinas sosial), pengenalan jaminan kesehatan nasional atau Kartu Indonesia Sehat (yang disampaikan oleh Syeni Ali), dan episode ke enam belas yang tayang pada 17 November 2020 membahas tentang pengelolaan air bersih yang disampaikan oleh Sony Salimi, yang semuanya dimulai dengan senam
Sekoper Cinta, pengantar dari pembawa acara yang dilakukan oleh Ketua Umum Sekoper Cinta, kemudian drama keluarga damai dan teori dari Master of Trainer Sekoper Cinta. ${ }^{38}$

Hal ini tentu membuat penyampaian materi lebih menarik dan jangkauannya semakin luas, serta tidak hanya dapat dinikmati oleh anggota Sekoper Cinta saja, tetapi juga oleh masyarakat Jawa Barat dan masyarakat luar Jawa Barat lainnya. Selain itu, Sekoper Cinta telah bekerja sama dengan Kementrian Kesetaraan Gender dan Keluarga Korea Selatan untuk mensukseskan program ini di Jawa Barat.

Kemudian pada Selasa 22 Oktober 2019, telah terdapat 2700 wisudawati yang berasal dari 100 desa dan 27 kabupaten dan kota di Jawa Barat diwisuda di Gymasium UPI Kota Bandung. Wisuda ini dihadiri oleh Gubernur dan Ineu Purwadewi Sundari selaku wakil ketua DPRD Jabar. Sebagai wakil ketua DPRD Jabar, perannya akan melakukan pengawasan, dukungan anggaran pada stakeholder untuk melakukan inovasi dalam gerakan Sekoper Cinta. Sebelum masuk tahapan wisuda, para anggota Sekoper Cinta akan melakukan ikrar yang salah satu bunyi ikrarnya ialah untuk mengusahakan keharmonisan keluarga. Kemudian setelah wisuda, akan ada pengkaderan wajib oleh tiap anggota, yang dibebankan tiga perempuan bagi setiap anggota Sekoper Cinta yang diwisuda, dan akan ada program lanjutan supaya wisudawati dapat mandiri secara finansial dan dapat belajar langsung terkait keterampilan yang diminati. Adapun sambutan Ridwan Kamil kepada para wisudawati diharapkan menerapkan empat nilai, yakni physical Quotient (PQ), Intellegence Quotient (IQ), Emotional Quotient (EQ), dan Spiritual Quotient (SQ) agar dapat mencetak sumber daya manusia (SDM) yang unggul

38 Kanal Youtube Sekoper Cinta pada https://www.youtube.com/channel/UCnIFvUPXkQ 94Fxszu3o68eg 
dan berdaya. Selain itu, para wisudawati adalah perempuan juara yang siap menjadi solusi bagi dirinya sendiri, keluarga dan lingkungan serta akan menjadi aktivis yang mengajak untuk bergabung di Sekoper Cinta

Dari paparan mengenai konsep dan tujuan program Sekoper Cinta, maka tidak dapat dipungkiri bahwa program ini sangat membantu dalam meningkatkan kualitas perempuan di Tatar Sunda. Terlebih program ini telah mendapat perhatian dan apresiasi dari kementrian PPPA (Pemberdayaan Perempuan dan Perlindungan Anak) Yohana Susana Yambise dan dianggap dapat diimplementasikan di tingkat nasional dan menjadi percontohan bagi daerah lain. Walau program Sekoper Cinta merupakan program baru, namun program ini merupakan program yang akan membantu perempuan Jawa Barat untuk berdaya dan berkualitas, sehingga mampu memiliki peran dan kesempatan yang sama dengan laki-laki.

Target usia pun dapat dikatakan tepat sasaran, karena banyaknya pernikahan di usia muda pada masyarakat Sunda, sehingga dapat membantu memperkuat ketahanan keluarga. Jika dilihat dari fungsi keluarga, program ini telah membantu seorang perempuan untuk dapat menjadi seorang ibu yang mampu berperan baik di dalam keluarga sesuai fungsi keluarga seperti fungsi biologis dalam pemenuhan kebutuhan yang diperkuat oleh fungsi ekonomi dengan materi pengembangan usaha yang didapatkan selama sekolah di Sekoper Cinta, kemudian fungsi perlindungan, kasih sayang, dan sosialisasi yang ditopang dengan segala macam materi tentang lingkungan dan diri yang akan mendorong kepada fungsi rekreatif dan menghadirkan keluarga yang nyaman, aman dan sejahtera. Serta fungsi pendidikan sebagai bentuk membantu perempuan siap dalam mendidik anaknya. Selain itu, dengan adanya program Sekoper Cinta dapat menjadi wadah untuk mewujudkan aktualisasi diri bagi perempuan atau sebagai proses menjadi diri sendiri dengan mengembangkan sifat-sifat dan keunikan diri sebagai potensi individu menjadi pribadi yang utuh. ${ }^{39}$ Upaya ini akan membawa perempuan untuk mengenali, dan memperbaiki dirinya, kemudian mengubah kondisi diri menjadi lebih baik lagi.

Tentu terdapat kaitan yang erat antara maslahat pendidikan anak, perbaikan keluarga dan pembinaan generasi. Di mana program Sekoper Cinta ini memberi materi pengetahuan yang dapat diterapkan dalam masa mendidik anak sebagai generasi bangsa di masa depan, yang mana cara mendidik anak tentu akan berpengaruh pada pola perilaku anak ke depan, maka tentu program ini memberi bekal untuk memperbaiki keluarga menjadi lebih baik guna membina generasi yang unggul. Selain itu dengan program ini, perempuan diajak untuk mandiri dan sigap dalam menghadapi peluang dan tantangan. Mandiri dalam ekonomi dengan perencanaan keuangan yang baik melalui industri rumahan yang kreatif, mandiri dalam menangani pengelolaan sandang pangan, mandiri dalam menanggapi permasalahan kesehatan dan kebersihan, dan hal lainnya yang telah dibina dalam program ini.

Dengan menerapkan pengetahuan dan materi yang didapat dari program ini, tentu akan melahirkan perempuan-perempuan unggul yang berkualitas, maju, tangguh dan kreatif yang juga mampu membantu menguatkan keharmonisan di dalam keluarga, sehingga dapat menekan angka perceraian. Terlebih karena perceraian terjadi karena faktor ekonomi, dengan program ini perempuan bisa membantu dalam menghasilkan uang atau setidaknya dapat mengatur keuangan dengan baik. Selain itu, teori manajemen konflik juga sangat berguna

${ }^{39}$ Deni Febrini, Bunga Rampai Islam dan Gender ., 133. 
ketika terjadi perselisihan atau pertengkaran yang memicu kepada perceraian. Secara tidak langsung, Sekoper Cinta telah menanamkan pentingnya ketahanan dan keharmonisan keluarga. Dengan adanya program ini pula, Pemprov Jawa Barat telah melakukan inovasi dalam pemberdayaan perempuan dan mendorong program prioritas Menteri PPPA tahun 2019-2024, yakni untuk mengefektifkan peran keluaga dalam pengasuhan anak untuk tidak bekerja, menikah dini, mengalami kekerasan, dan pemberdayaan perempuan di bidang kewirausahaan.

\section{Kesimpulan}

Program Sekoper Cinta merupakan sekolah perempuan masa kini yang sangat membantu masyarakat, khususnya seorang perempuan untuk lebih berdaya dan berkualitas, sehingga ketika telah menjadi seorang ibu dapat melakukan perannya dengan baik dan mencapai fungsinya sebagai pendidik pertama di dalam keluarga. Selain itu, materi yang diberikan dapat menjadi penguat ketahanan keluarga, sehingga jika dipraktikan dapat menjadi counter dan pencegah adanya perceraian. Dengan adanya program ini, tentu bisa menjadi suatu harapan untuk menekan angka percertaian tinggi di Jawa Barat, kasus kekerasan, perdagangan manusia dan kasus stunting yang terjadi di Tatar Sunda ini. Hal ini tentu dapat diterapkan oleh daerah lain secara nasional untuk memberdayakan perempuan, memperkuat ketahanan keluarga, dan membebaskan perempuan dari ketidakadilan gender.

Namun target Sekoper Cinta juga diharapkan bisa diikuti oleh laki-laki, sehingga dalam mencapai keluarga yang sakinah, mawaddah, warahmah dan maslahat dapat dilakukan secara bersama-sama tanpa beban. Mengingat laki-laki juga perlu mendapat materi tentang keperempuanan dan kesalingan dalam relasi suami istri. Selain itu, pemberitaan sekoper Cinta dapat didokumentasikan secara khusus melalui website tertentu, sehingga dapat menjadi panduan dan pengetahuan bagi daerah lain dan juga bagi masyarakat di Indonesia pada umumnya.

\section{Daftar Pustaka}

\section{Buku Teks}

Febrini, Deni, (2017) Bunga Rampai Islam dan Gender. Yogyakarta: Pustaka Pelajar.

Nashih Ulwan, Abdullah, (2012), Pendidikan Anak dalam Islam (Tarbiyatul Aulad fil Islam), Penterj. Arif Rahman Hakim dan Abdullah Halim. Solo: Insan Kamil.

Qibtiyah, Alimatul, (2018), Feminisme Muslim di Indonesia. Yogyakarta: Penerbit Suara Muhammadiyah.

Ruhaini Dzuhayatin, Siti, (2015), Rezim Gender Mubammadiyah. Yogyakarta: Suka Press UIN Sunan Kalijaga Yogyakarta dan Pustaka Pelajar.

Salahudin, Asep, (2017), Sufisme Sunda: Hubungan Islam dan Budaya dalam Masyarakat Sunda. Bandungh: Penerbit Nuansa.

Suryani, Elis, (2011), Ragam Pesona Budaya Sunda. Bogor: Penerbit Ghalia Indonesia.

\section{Jurnal Ilmiah}

Anjani Nurlatifah, dkk, Dini. "Proses Pemberdayaan pada Program Sekolah Perempuan Capai Impian da Cita-cita (Sekoper Cinta)", Az-Zahra, Vol.1 No. 1, 2020.

Aswiyati, Indah, Peran Wanita dalam Menunjang Perekonomian Rumah Tangga Keluarga Petani Tradisional Untuk Penanggulangan Kemiskinan Di Desa Kuwil Kecamatan Kalawat, Jurnal Holistik, No. 17, 2016, h. 5.

Deliana, Nurfarida, Gerakan Emansipasi Ruhana Kuddus dalam Memperjuangkan Kesetaraan Pendidikean Perempuan di Minangkabau, Humanisma:Journal of 
Gender Studies , Vol 03 No. 02, 2019, h. 171.

Efendy, Rustan, Kesetaraan Gender Dalam Pendidikan, Jurnal Al-Maiyyah, Volume 07 No. 2, 2014, h. 156.

Hanapi, Agustin. Peran Perempuan Dalam Islam, Gender Equality: Internasional Journal Of Child And Gender Studies, Vol. 1, No. 1, 2015, h. 16.

Hani Almasitoh, Ummu. Model Terapi dalam Keluarga, Jurnal Magistra, No. 08, 2016, h. 27.

Heryana, Agus, Mitologi Perempuan Sunda, Jurnal Patanjala, Vol. 4, 2012, h. 167.

Isnenders dan Ucu Firmansyah, Retty . Masyarkat Sunda dalam Sastra: Komparasi Moralitas dan Kepribadian, Jurnal Lokabasa, Vol. 4, 2013, h. 89.

Jasmienti dan Nofrianti Putri Utami, Peran Perempuan Single Mother dalam Keluarga Miskin di Jorong Balai Mansiro Nagari Guguak VIII Koto, Humanisma: Journal of Gender Studies, Vol. 3, No. 02, 2019, h. 130.

Lestari, Dian. Eksistensi Perempuan dalam Keluarga (Kajian Peran Perempuan sebagai Jantung Pendidikan anak), Muwazah, Vol. 8, No. 2, 2016, h. 259.

Muhammad, Husein. Islam dan Pendidikan Perempuan, Jurnal Pendidikan Islam, Vol. III, No. 2, 2014, h. 238.

Pawitasari, Erma. Pendidikan Khusus Perempuan antara Kesetaraan Gender dan Islam, Tsaqafah, Vol. II, No. 2, 2015, h. 264.

Pidarta, Made. Peranan Ibu Dalam Pendidikan Anak, Jurnal Ilmu Pendidikan, Vol. 4 Nomor 4, 1997, 241.

Rakhmawati, Istina. Peran Keluarga dalam Pengasuban Anak, Jurnal Bimbingan Koseling Islam, Vol. 6, 2015, h. 7.

Rofiah dan Kustini, Nur. Perkawinan di Bawah Umur Potret Buram Anak Perempuan di Cainjur. Jurnal Harmoni. 2014, h. 148.

Rofiah, Nur. Kekerasan Dalam Rumah Tangga Dalam Perspektif Islam. Jurnal Wawasan: Jurnal Ilmiah Agama dan Sosial Budaya. Vol. 1. 2017, h. 4142.

Safaruddin dan Jumanto, Peran Ibu dalam Pendidikan Keluarga Untuk Mendukung Keberbasilan Pendidikan Formal Anak di Sekolah Dasar, Jurnal Profesi Pendidik, Vol. 3, 2016, h. 45.

Siri, Hasnani. Gender Dalam Perspektif Islam, Jurnal Al-Maiyyah, Volume 07 No. 2, 2014, h. 247.

Syahran Jailani, M. Teori Pendidikan Keluarga dan Tanggung Jawab Orang Tua dalam Pendidikan Anak Usia Dini, Nadwa: Jurnal Pendidikan Islam, Vol. 8 No. 2, 2014, 246.

Wahyu Sururie dan Harry Yuniardi, Ramdani. Perceraian Dalam Keluarga Muslim di Jawa Barat, Jurnal Al-Manahij, Vol. 12, 2018, h. 272.

Yulianty Iskandar, Rani. Citra Perempuan Sunda di Dalam Karya Sastra dan Film", Jurnal Sosioteknologi, edisi 26 , 2012, h. 99.

Zuwardi, Peran Perempuan dalam Mewujudkan Keluarga Sejabtera Menurut Perspektif Ekonomi Islam (Studi Kasus Perempuan Pedagang Kaki Lia di Simpang Tugu Togo Baleh, Kelurahan Pakan Labuba, Kota Bukittinggi, Humanisme:Journal of Gender Studies , Vol 04 No. 01, 2020, h. 65.

\section{Makalah Ilmiah dan Artikel}

Fitri Febriyanti, Tirza. Pemberdayaan Perempuan dalam Menngkatkan Pendidikan Karakter Melalui Program Sekoper Cinta (Sekolah Perempuan Capai Impian dan Cita-Cita) di Kota Bandung: Studi Deskriptif DP3APM Kota Bandung (Skrispi Universitas Pendidikan Indonesia, 2019). 
Zahrok dan Wayan Suarmini, Siti. Peran Perempuan dalam Keluarga, Prosiding $\begin{array}{lll}\text { Semateksos } & 3 & \text { Startegi }\end{array}$ Pembangunan Nasional Menghadapi Revolusi Industri 4.0.

\section{Referensi Online dan Wawancara}

Akmal, Thareq. "Tiga Provinsi dengan Jumlah Perceraian Tertinggi”, https://smartlegal.id/smarticle/laya nan/2018/12/20/tiga-provinsidengan-jumlah-perceraian-tertinggi, diakses pada tanggal 21 November 2019.

https://cianjur.pojoksatu.id/baca/kiprah-sitijenab-di-dunid-pendidikansemangat-juang-mencerdaskanmasyarakat-cianjur

https://www.jelajahgarut.com/raden-ayulasminingrat

Kasim, "Kasus Kekerasan Anak dan Perempuan Ada di Jawa Barat", https://fokusjabar.com/m/beritapantura/kasus-kekerasan-anak-danperempuan-tertinggi-ada-di-jawabarat-h32714.html, diakses pada tanggal 21 November 2019.

Retno, Windiyati. “Ada 819 Kekerasan pada Anak di Jabar selama 2018 Terbanyak Sukabumi”, https://www.pikiran-

rakyat.com/jawabarat/2019/04/03/ada-819-kasuskekerasan-pada-anak-di-jabar-2018terbanyak-di-sukabumi, diakses pada tanggal 21 November 2019.

Surya. "Modul Sekoper Cinta Kota Sukabumi", https://id.scribd.com/document/4 14590694/Modul-Sekoper_Cinta-de-f diakses pada 19 September 2020.

Sutrisno, Debbie. "Turunkan Angka Stunting, Pemprov Jabar Luncurkan Desa Cageur", https://jabar.idntimes.com/newa/ja bar/debbie-sutrisno/turunkanangka-stunting-pemprov-jabar- luncurkan-desa-cageur/full, diakses pada Kamis 21 November 2019.

www.disparbud.jabarprov.go.id/wisata/

www.intagram/sekoper cinta

https://www.youtube.com/channel/UCnIFv

UPXkQ94Fxszu3o68eg 